\title{
Is Relying on Title IX a Mistake?
}

\author{
Corey Rayburn Yung*
}

INTRODUCTION

Universities ${ }^{1}$ have, until recently, turned a blind eye toward sexual assault committed by and against their students. ${ }^{2}$ The best available research indicates that approximately one in five women at universities are sexually assaulted. ${ }^{3}$ Although there is less reliable data regarding the victimization $^{4}$ rates of men and transgender persons at higher education

* Professor of Law at the University of Kansas School of Law. I am grateful to my fellow participants at the live portion of the symposium-Katharine K. Baker, Aya Gruber, Chrissy Heikkila, Tamara Rice Lave, and Chrysanthi S. Leon-for their thoughtful comments that have helped me immensely. I would also like to thank the members of the Kansas Law Review, especially Abby Hall and Bryce Langford, for their incredible support and patience throughout the symposium and subsequent publication process.

1. For reasons of simplicity and efficiency, this Article refers collectively to colleges, universities, and other similar higher education institutions in the United States as "universities."

2. See Lavinia M. Weizel, Note, The Process That Is Due: Preponderance of the Evidence as the Standard of Proof for University Adjudications of Student-on-Student Sexual Assault Complaints, 53 B.C. L. REV. 1613, 1614 (2012).

3. See Christopher P. Krebs et al., The Campus Sexual Assault (CSA) Study, NAT'L INST. OF JUSTICE xii (Oct. 2007), https://www.ncjrs.gov/pdffiles1/nij/grants/221153.pdf. These statistics have been subject to immense scrutiny leading many members of the media to conclude that they have been "debunked" or the product of a "hoax." See, e.g., Ian Tuttle, Is the Party Over? The Fight for the Future of Fraternities, NAT'L REV., Apr. 6, 2015, at 29 (“Alarmists continue to tout the debunked statistic that one woman in five will be assaulted in her college years, to bolster the notion that campuses are beset by a sexual-assault 'epidemic' requiring swift, forceful action."); Glenn Harlan Reynolds, The Great Campus Rape Hoax, USA TODAY (Dec. 15, 2014, 9:40 AM), http://www.usatoday.com/story/opinion/2014/12/14/campus-rape-uva-crisis-rolling-stone-politicscolumn/20397277/. Those conclusions are not only unwarranted; they are not based upon sound consideration of the social science methods and data involved. It is beyond the scope of this Article to debate the alleged problems with the survey data. I have remarked in other forums about our lack of high-quality data in this area. Corey Rayburn Yung, College Campus Rape Statistics, CONCURRING OPS. (May 13, 2014), http://concurringopinions.com/archives/2014/05/collegecampus-rape-statistics.html. Nonetheless, it is important to note that the scholarly consensus has found that the best data that exists shows a rate of sexual assault victimization as one-in-five to onein-four among women at universities. See Christopher Krebs et al., Campus Climate Survey Validation Study: Final Technical Report, Bureau of Justice Statistics Research \& Dev. SERIES (2016), http://www.bjs.gov/content/pub/pdf/ccsvsftr.pdf.

4. There is no consensus about whether it is better to refer to those who have been raped as victims or survivors. Some prefer the term survivor because it focuses on how a person has moved past their experience of sexual violence. See, e.g., Rhona Dowdeswell, Why I Must Forgive to Get Over My Rape; Analysis, W. DAILY PRESS, Jan. 25, 2002, at 8 . In contrast, Andrea Dworkin offered this explanation for why she thought the victim label was more appropriate: 
institutions, those populations likely suffer high rates of sexual violence as well. ${ }^{5}$ Despite those well-known and well-worn statistics, university leadership continues to underestimate the rate and amount of sexual violence among students. A 2015 Gallup and Inside Higher Ed anonymous survey of 647 college presidents found that just $32 \%$ either strongly agreed or agreed that sexual assault was "prevalent at American colleges and universities." Remarkably, only 6\% either strongly agreed or agreed that sexual assault was "prevalent at their institution."

The disjunction between those two percentages indicates that even among university leaders who recognize the campus reality of sexual violence, they overwhelmingly view it as some other school's problem to address. It follows from those findings that a mere $4 \%$ of those surveyed strongly disagreed or disagreed that their campuses were "doing a good job" protecting women from sexual assault at their universities. ${ }^{8}$ Given

It's a true word. If you were raped, you were victimized. You damned well were. You were a victim. It doesn't mean that you are a victim in the metaphysical sense, in your state of being, as an intrinsic part of your essence and existence. It means somebody hurt you. They injured you. And if it happens to you systematically because you are born a woman, it means that you live in a political system that uses pain and humiliation to control and to hurt you.

Andrea Dworkin, Woman-Hating Right and Left, in THE SEXUAL LIBERALS \& THE ATTACK ON FEMINISM 28, 38 (Dorchen Leidholdt \& Janice G. Raymond eds., 1990). Others prefer the term victim because it better enables them to confront their past experience of rape. See, e.g., Dana Bolger, "Hurry Up and Heal": Pain, Productivity, and the Inadequacy of 'Victim vs. Survivor', FEMINISTING (Dec. 10, 2014), http://feministing.com/2014/12/10/hurry-up-and-heal-painproductivity-and-the-inadequacy-of-victim-vs-survivor/ ("Compulsory survivorship depoliticizes our understanding of violence and its effects. It places the burden of healing on the individual, while comfortably erasing the systems and structures that make surviving hard, harder for some than for others. You are your own salvation. You are your own barrier to progress."); Kate E. Bloch, A Rape Law Pedagogy, 7 YALE J.L. \& FEMINISM 307, 308 n.6 (1995). In this Article, I use the term victim because of those latter arguments and because it is a label that connects those who have been raped with the universal category of crime victims. Nonetheless, I recognize this decision conflicts with the conclusions of some persons who have been raped and for that, I sincerely apologize.

5. See Marjorie R. Sable et al., Barriers to Reporting Sexual Assault for Women and Men: Perspectives of College Students, 55 J. Am. Coll. HeAlth 157, 159 (2006). Students at universities are typically within the prime age range for being sexually victimized and, as a result, it is unsurprising that such locations would have alarming levels of sex abuse. See Bonnie S. Fisher et al., The Sexual Victimization of College Women, NAT'L INST. OF JusTICE iii (2000), https://www.ncjrs.gov/pdffiles1/nij/182369.pdf ("College campuses host large concentrations of young women who are at greater risk for rape and other forms of sexual assault than women in the general population or in a comparable age group.").

6. Scott Jaschik \& Doug Lederman, The 2015 Inside Higher Ed Survey of College \&

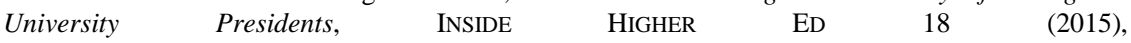
http://big.assets.huffingtonpost.com/2015IHE_PresidentsSurvey.pdf.

7. Id.

8. Id. at 19 (indicating that $1 \%$ strongly disagreed and $3 \%$ disagreed with the statement that "My campus is doing a good job protecting women from sexual assault on my campus"). 
those attitudes and beliefs, it is not at all shocking that universities throughout the United States-more concerned with marketing than student safety-have "rebranded" incidents of rape as "nonconsensual sex." 9

Against this backdrop, Title IX of the United States Education Amendments of 1972 (Title IX) has become virtually synonymous with campus rape adjudication in the public and legal debates surrounding the contentious topic. ${ }^{10}$ Indeed, many have been optimistic that the growing role of Title IX will give universities the push they need to adequately address student sexual violence. ${ }^{11}$ In evaluating what future course universities should take, this Article attempts to answer an essential question related to Title IX's role in student sexual assault at universities: is it better to improve and universalize student safety and conduct codes or rely on the new Title IX framework that has emerged?

The tentative answer offered is that it is a mistake to solely or primarily depend on Title IX to deter and punish offenders in university sexual assault cases. This conclusion is based upon the uncertainty related to various aspects of Title IX doctrine and the regulatory regime that has emerged to enforce the statute. Consequently, this Article concludes Congress should adopt a basic, uniform student safety and conduct code that will cure many of the shortcomings of a legal regime based entirely upon Title IX. This legislation, unlike proposals aimed at merely strengthening the Title IX framework, might potentially avoid some of the backlash that has emerged in the wake of Title IX's growing application in student-to-student sexual assault cases at universities while better addressing the issue.

Section I of this Article discusses the shortcomings of a regulatory and tort regime in addressing university sexual assault cases based upon Title IX. Section II outlines potential legislation for a universal student code of conduct as well as the advantages of such a system versus one

9. See Claire Gordon, 'Nonconsensual Sex': How Colleges Rebranded Rape, AL JAZEERA AMERICA (Apr. 17, 2014, 4:00 PM), http://america.aljazeera.com/watch/shows/americatonight/articles/2014/4/17/nonconsensual-sexwhenrapeisreworded.html (describing how the leading Title IX consultant, Brett Sokolow, made "nonconsensual sex" the new "industry standard" for referring to rape by encouraging its use by universities).

10. 20 U.S.C. $§ 1681$ (a) (2012) ("No person in the United States shall, on the basis of sex, be excluded from participation in, be denied the benefits of, or be subjected to discrimination under any education program or activity receiving Federal financial assistance ....").

11. See, e.g., Katharine K. Baker, Why Rape Should Not (Always) Be a Crime, 100 MinN. L. REV. 221, 224 (2015). 
relying exclusively on Title IX. This Article concludes with some tentative thoughts about the future of campus sexual assault adjudication.

\section{TITLE IX AND INSTITUTIONAL INDIFFERENCE}

Title IX exists in two related, but separate, forms in relation to sexual assaults of university students. The statute, as originally enacted as part of the United States Education Amendments of 1972, provides that: "No person in the United States shall, on the basis of sex, be excluded from participation in, be denied the benefits of, or be subjected to discrimination under any education program or activity receiving Federal financial assistance ...."12 As such, Title IX serves as a cause of action for sex discrimination. ${ }^{13}$ As a basis for a tort claim, a student or group of students may sue their university for contributing to a hostile educational environment by failing to properly address sexual assault. ${ }^{14}$

More recently, the Department of Education (DoE) Office of Civil Rights (OCR) identified Title IX as the foundation for administrative guidance documents specifically targeted at sexual assault in the form of Dear Colleague Letters (DCLs). ${ }^{15}$ The regulatory guidance application of Title IX does not necessitate court litigation for addressing instances of sexual violence. ${ }^{16}$ It is largely administered through DoE investigations of universities following student complaints made to the DoE. ${ }^{17}$ These two functions of Title IX potentially raise different concerns about the statute's role in campus sexual assault cases that are sometimes addressed separately throughout this Section. In either form, there are reasons to believe that Title IX is a less-than-ideal vehicle for addressing sexual assault on its own.

\footnotetext{
12. 20 U.S.C. $§ 1681(\mathrm{a})$.

13. Jackson v. Birmingham Bd. of Educ., 544 U.S. 167, 169 (2005).

14. Davis v. Monroe Cty. Bd. of Educ., 526 U.S. 629, 644 (1999).

15. Letter from Russlynn Ali, Assistant Sec'y for Civil Rights, U.S. Dep't of Educ. to Title IX Coordinators (Oct. 26, 2010) [hereinafter 2010 Dear Colleague Letter], http://www2.ed.gov/about/offices/list/ocr/letters/colleague-201010.pdf; Letter from Russlynn Ali, Assistant Sec'y for Civil Rights, U.S. Dep't of Educ. to Title IX Coordinators (Apr. 4, 2011) [hereinafter 2011 Dear Colleague Letter], http://www2.ed.gov/about/offices/list/ocr/letters/colleague-201104.pdf.

16. Alison Renfrew, Comment, The Building Blocks of Reform: Strengthening Office of Civil Rights to Achieve Title IX's Objectives, 117 PENN ST. L. Rev. 563, 571 (2012).

17. Id. at $572-73$.
} 


\section{A. Sexual Assault as Sexual Harassment}

Many of the shortcomings related to Title IX's application to peerto-peer sexual assault cases arise because the statute, by its own terms, must confront such cases as a form of sexual harassment which, in turn, is a form of sex discrimination. Figure 1 shows how the Title IX framework works in this regard.

\section{Figure 1: Title IX's Application to Sexual Assault Cases}

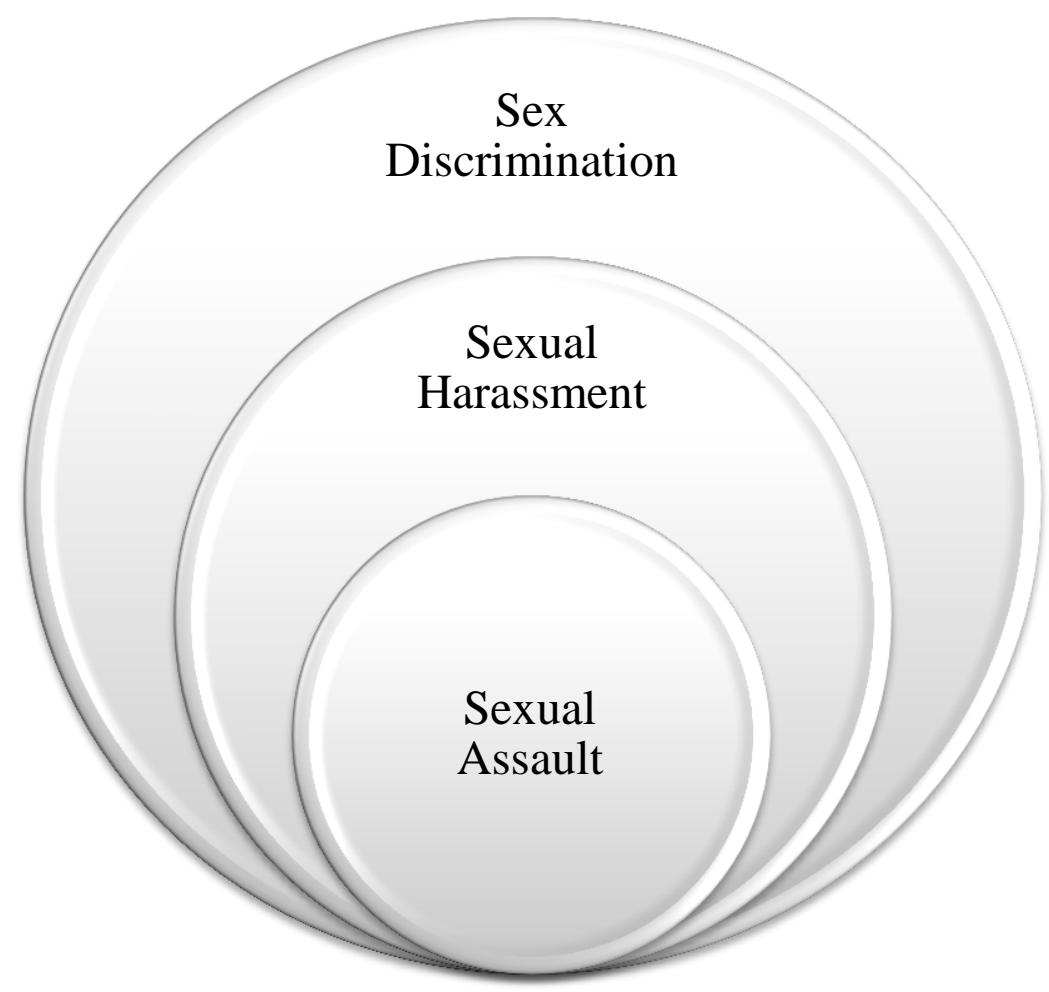

Despite the assumption that sexual assault is a subset of sexual harassment, there are numerous differences between university sexual assault cases and the more typical sexual harassment claims brought under Title IX. 
Examining the structure of a Title IX cause of action helps to illustrate the sometimes imperfect fit between the statute and peer-topeer sexual assault cases. In 1999, the Supreme Court of the United States, in Davis v. Monroe County Board of Education, set out the elements necessary to establish a claim under Title IX for sexual harassment as:

1. Defendant is a federally funded institution;

2. And had actual knowledge of the sexual harassment;

3. That was so severe, pervasive, and objectively offensive;

4. To which the institution exhibited deliberate indifference; and

5. That the victim was effectively barred the access to an educational opportunity or benefit as a result of the sexual harassment. ${ }^{18}$

Meeting the latter four requirements is often too high of a bar for plaintiffs in university sexual assault cases. ${ }^{19}$

Consider the 2013 case of Carabello v. New York City Department of Education, brought in the Eastern District of New York. ${ }^{20}$ The court held that the plaintiff had failed, as a matter of law, to prove that the sexual abuse she suffered supported a legal cause of action even though the defendant, a fellow student, was alleged to have, over forceful and verbal objections, "touched [the victim] all over, including her legs, stomach, and breasts, and bit her on the neck." 21 The court held that, under Davis, the plaintiff would have to have suffered injury akin to penetrative rape for it to meet the severe and pervasive requirement with only a single incident of sexual abuse. ${ }^{22}$ It wrote:

18. See Davis, 526 U.S. at 633 (requiring a plaintiff to show "the funding recipient acts with deliberate indifference to known acts of harassment in its programs or activities. Moreover, we conclude that such an action will lie only for harassment that is so severe, pervasive, and objectively offensive that it effectively bars the victim's access to an educational opportunity or benefit").

19. See Grayson Sang Walker, Note, The Evolution and Limits of Title IX Doctrine on Peer Sexual Assault, 45 HARV. C.R.-C.L. L. REV. 95, 111 (2010).

20. Carabello v. N.Y.C. Dep't of Educ., 928 F. Supp. 2d 627 (E.D.N.Y. 2013) (adopting the report and recommendation of the magistrate judge).

21. See id. at 635, 644, 648 (granting summary judgment for defendants on Title IX sexual harassment claims as well as Title IX retaliation claims, state law negligent infliction of emotional distress claim, and state law negligent supervision claim).

22. See id. at 643 (citing Davis, 526 U.S. at 650, 652). 
M.H. was not raped, nor did she experience a "serious" sexual assault. The extent of her abuse consisted of B.P. putting all of his weight on her, touching her breasts, stomach and legs over her clothing, and biting her neck hard enough to leave a mark. Undoubtedly, this behavior is inappropriate and should not to be condoned; however, this conduct does not arise to the level of "sufficiently severe, pervasive, and objectively offensive" as a matter of law.

The holding in Carabello has been, unfortunately, fairly typical. ${ }^{24}$ As one commentator observed, Title IX doctrine "practically immunizes schools from liability in Title IX suits involving peer sexual harassment in all but the most extreme cases." 25 Even when such lawsuits have been successful, final resolution of the litigation has often been when both the perpetrator and victim have left the university.

For both the Title IX cause of action and the DCL regulatory framework, there is also the very real problem that jurisdiction literally ends at the campus doorsteps. ${ }^{26}$ The result of this inherent limitation is that sexual assault victims must show that their abuse deprived them "access to the educational opportunities or benefits provided by the school., ${ }^{27}$ This requirement can be difficult for many plaintiffs to meet. If a plaintiff does not show clear evidence of a decline in academic performance due directly to sexual victimization or denial of university services, Title IX might not apply.

Returning to the Carabello case, the court addressed the "educational opportunities or benefits" element as well. ${ }^{28}$ The court found that even if the plaintiff's claim met the severe and pervasive requirement, a high burden existed to show actual deprivation of educational opportunities. ${ }^{29}$ It concluded that although the victim/survivor had "been diagnosed with [post-traumatic stress disorder] and suffer[ed] from flashbacks and nightmares," she failed to show "declining grades and other evidence of a "concrete negative effect' on [her] education." 30 The sexual harassment

23. Id.

24. See Walker, supra note 19, at 106-14; Diane L. Rosenfeld, Concluding Remarks, Changing Social Norms? Title IX and Legal Activism, 31 HARV. J.L. \& GENDER 407, 407-08, 412 (2008) (summarizing key issues discussed during the "Changing Social Norms? Title IX and Legal Activism" Harvard Journal of Law \& Gender Conference, including "the stringent standards imposed on victims bringing Title IX cases against educational institutions for sexual harassment").

25. Walker, supra note 19 , at 100.

26. See Office for Civil Rights, U.S. Dep't of Educ., Case Processing Manual 6-8 (2015), http://www2.ed.gov/about/offices/list/ocr/docs/ocrcpm.pdf.

27. Davis v. Monroe Cty. Bd. of Educ., 526 U.S. 629, 650 (1999).

28. Carabello, 928 F. Supp. $2 \mathrm{~d}$ at $642-44$.

29. Id. at 643-44.

30. Id. 
lens of a Title IX cause of action in cases involving accusations of peerto-peer sexual violence necessitates that plaintiffs surpass these legal bars, a challenge that many claims simply cannot meet.

\section{B. Legal Status of Dear Colleague Letters}

In an ideal world, the DCL regulatory scheme would supplement Title IX's cause of action to avoid some of those deficiencies of court litigation. However, the legal status of the DCLs has not been fully vetted in the courts to determine if it can fill the current vacuum. ${ }^{31}$ The critical legal question for the DCLs is whether they are consistent with the law and doctrine emerging from the Administrative Procedure Act (APA) and administrative law more generally. ${ }^{32}$ Although many associate the APA with formal rulemaking procedures that implement statutes, there is a recognized role for informal regulatory guidance documents like the DCLs as well. ${ }^{33}$ The questions that remain are: 1) what force of and role in law does such informal guidance have; and 2) are the DCLs consistent with Title IX and the formal regulations effecting it?

It is beyond the scope of this Article to offer a definitive opinion as to either the best interpretation of the APA or how the courts will actually decide the issue. Rather, my goals here are to establish that there is at least some uncertainty on the questions involved and anticipate the fallout if at least some courts hold that the DCLs are inconsistent with the APA.

The basic argument against a strong legal role for the DCLs is that they are beyond the scope of what both the APA and Title IX would warrant. $^{34}$ Critics contend that the two most recent DCLs constitute

31. See Robert A. Anthony, Interpretive Rules, Policy Statements, Guidances, Manuals, and the Like-Should Federal Agencies Use Them to Bind the Public?, 41 DuKE L.J. 1311, 1326-27 (1992).

32. See id. at 1312 .

33. See Ming Hsu Chen, Governing by Guidance: Civil Rights Agencies and the Emergence of Language Rights, 49 HARV. C.R.-C.L. L. REV. 291, 302 (2014) (“Although not specifically mentioned in the APA exceptions, guidances can also take the form of Dear Colleague letters, memoranda of understandings, compliance manuals, and even press releases setting out agency positions. Collectively, guidances constitute a major form of regulatory action in the modern state.").

34. See Jake New, Guidance or Rule Making?, INSIDE HIGHER ED (Jan. 7, 2016), https://www.insidehighered.com/news/2016/01/07/senators-challenge-legality-us-guidance-campussexual-assault. Quoting a letter from Senator James Lankford, the article explained:

In a sharply worded missive, Senator James Lankford wrote that, while the department's two Dear Colleague letters on harassment and sexual violence sent to institutions in 2010 and 2011 "purport to merely interpret statements of existing law," the letters actually 
rulemaking without having proceeded with the APA process for formal rulemaking. ${ }^{35}$ Several federal congresspersons have made this argument and, depending upon the results of the 2016 presidential election, Congress could enact a law invalidating the DCLs based upon those arguments. $^{36}$ However, even if the opposition of legislators goes nowhere, the federal courts could make the same findings and invalidate the DCLs. The very real concern that the DCLs could be summarily discarded is heightened if courts agree with critics that the guidance documents deviate from prior interpretations of the scope of Title IX. Given the paucity of case law in the area and the discretion afforded to judges, such a possibility needs to be considered.

If courts invalidate the DCLs, universities would be empowered to discard the adjudication processes that have emerged since the DCLs were issued. In that case, campuses might revert to a system of justice that is inherently arbitrary and hidden behind closed doors. This scenario may not come to pass, but it is important to consider it. If Congress enacts legislation-examples of which have so far failed to gain traction $^{37}$ - that essentially codifies the DCLs, this concern would be well addressed. However, given the difficulty of legislators supporting DCL codification, it might be worth considering alternative legislation, such as that discussed in Section II, which has the same effects with possibly less resistance attached.

\section{Conflicts of Interest and Intransigence}

University administrators have been reluctant to confront the problem of sexual violence at their schools, which heightens the concerns expressed above. Recent research and events have shown how indifference to sexual violence at universities manifests. For example, I recently completed an empirical study that found the general practice of universities has been to substantially undercount incidents of sexual violence and only make increased efforts toward addressing the problem during very limited periods of heightened government auditing and

enacted sweeping regulatory changes without first going through the required notice-andcomment procedures required by the Administrative Procedure Act.

Id.

35. See id.

36. See id.

37. See Julie Novkov, Equality, Process, and Campus Sexual Assault, 75 MD. L. REv. 590, 596-97 (2016); Stephen Henrick, A Hostile Environment for Student Defendants: Title IX and Sexual Assault on College Campuses, 40 N. Ky. L. REv. 49, 62 n.60 (2013). 
scrutiny. ${ }^{38}$ Consistent with my research, Diane Moyer, the Legal Director of the Pennsylvania Coalition Against Rape, gave a shocking and sobering assessment of those in the field regarding the reported number of sexual assaults at universities: "This will sound counterintuitive, but I actually tell parents to send their kids to the college or university with the highest number of sexual assaults reported through the Clery Act, because these schools are probably the most aware of the campus sexual assault problems." 39

Indeed, anyone who believes that universities have been accurately assessing and reporting the rate of sexual assault among students should take a close look at the data produced by Pennsylvania State University (Penn State). As demonstrated in Figure 2 below, Penn State's selfreported rates of sexual assault produced as required by the Clery Act, underwent a remarkable change after $2010 .^{40}$

38. See Corey Rayburn Yung, Concealing Campus Sexual Assault: An Empirical Examination, 21 PSYCHOL. PUB. POL'Y \& L. 1, 4 (2015) ("The study posits that an increase in the sexual assault rate during an audit is indicative of undercounting, because the heightened scrutiny increases compliance in reporting.").

39. Police Exec. Research Forum, Improving the Police Response to SeXual Assault 23-24 (2012) (quoting Diane Moyer, Legal Dir., Pa. Coal. Against Rape), http://www.policeforum.org/assets/docs/Critical_Issues_Series/improving\%20the\%20police\%20resp onse\%20to\%20sexual\%20assault\%202012.pdf. The full name of what is commonly known as the Clery Act is the "Jeanne Clery Disclosure of Campus Security Policy and Campus Crime Statistics Act.” 20 U.S.C. § 1092(f) (2012).

40. Figure 2 appeared in my previously mentioned study of university sexual assault statistics. See Yung, supra note 38, at 5. 


\section{Figure 2: Penn State Reported Sexual Assault Rates}

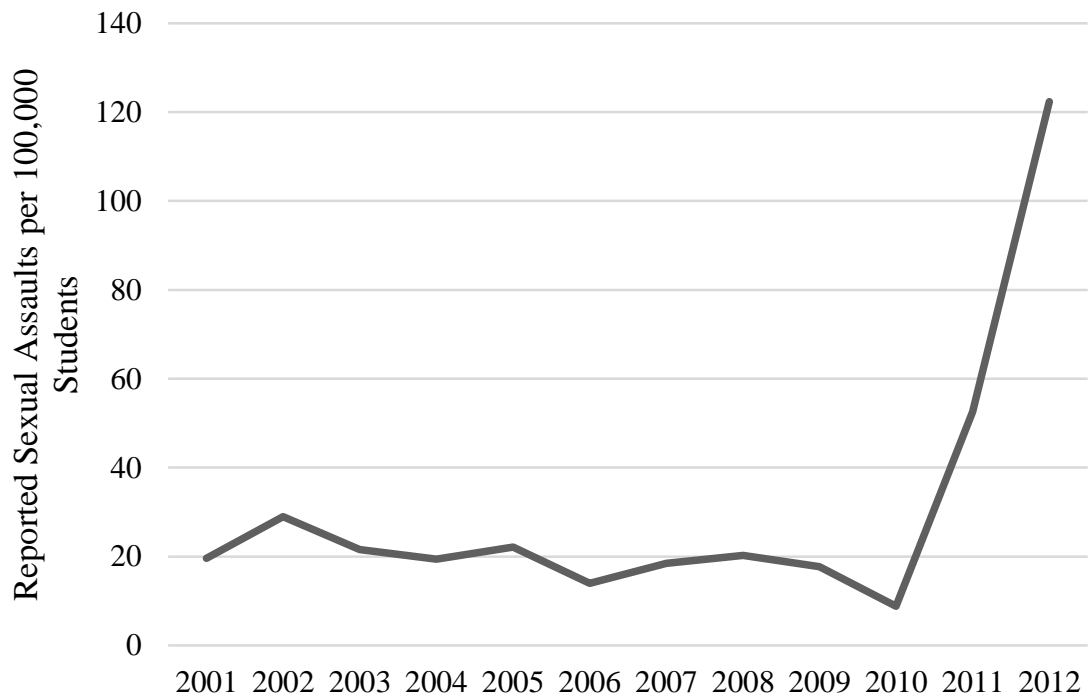

Prior to 2010, Penn State's reported rates of sexual assault were typical of what other large universities were submitting to the Department of Education. ${ }^{41}$ However, a pivotal moment in Penn State's history: the news about Jerry Sandusky's long-term sexual abuse of children broke. ${ }^{42}$ As a result of the media coverage and evidence of institutional failure at Penn State, the school received unprecedented regulatory scrutiny as federal officials from the Department of Education transformed the school's compliance practices concerning sexual violence reporting and administration. ${ }^{43}$ Under the watchful eye of the federal government, the school reported an astounding 1389\% increase in sexual assault rates in a two-year window. ${ }^{44}$ Penn State went from a school reporting run-of-the-mill sexual assault rates to rates twice as high as any of the other over-11,000 schools required to report such data under the Clery Act. ${ }^{45}$

\footnotetext{
41. See id.

42. See Mark Viera, A Sex Abuse Scandal Rattles Penn State's Football Program, N.Y. Times, Nov. 6, 2011, at A1.

43. See Adam Smeltz, \$60M Could Thwart Trials, PITTSBURGH TRIB. ReV., Jul. 20, 2013, LN ("The Sandusky scandal brought Penn State under similar scrutiny, with federal reviewers examining whether the school met reporting requirements when Sandusky was abusing boys.").

44. Yung, supra note 38, at 4.

45. See id. at 4-5.
} 
The reluctance of university officials to properly address sexual assault has implications for determining the desirability of which scheme is chosen to address the problem. If even some universities are engaged in aggressive resistance to federal regulation, the administrative rules chosen need to be clear and specific to ensure compliance.

Thus, the behavior of universities during the last decade should give pause to observers who believe that the Title IX approach to sexual assault is sufficient. Traditionally, Title IX litigation and regulation has been focused on addressing unlawful disparities in athletic departments and sex discrimination in hierarchal relationships. In such cases, the complainant is necessarily in an adverse position to the university because any liability will be borne by the university. Ideally, in a sexual assault case involving two student peers, the university would not need to be aligned with either party. Yet, Title IX forces the issue because any liability will be institutional and not individual.

Consider how a typical sexual assault complaint might proceed as follows according to the terms of the DCLs:

Vaughn reports to the university being sexually assaulted by Devin. Devin denies the allegation. After investigation, a university official will decide whether there is sufficient evidence to proceed with an administrative hearing to determine fault - a difficult decision in a case with conflicting narratives and little else. Assuming there is a hearing and Devin is found to have sexually assaulted Vaughn, Devin will receive some form of sanction (up to expulsion from the university). In response, Devin might file a lawsuit against the university. However, if the hearing finds insufficient evidence to support the sexual assault complaint or if the administrator decides there is insufficient evidence for a hearing, Vaughn might file suit.

Because the university might be sued in either case, likely under Title IX in both situations, it is in a situation ripe with potential conflicts of interest. A litigation-averse university will likely pursue the course least likely to create civil liability. This might include lesser punishment for Devin, assuming Devin will not sue if merely assigned to write a reflection paper. It might decide a hearing only creates a written record to be used against the university in subsequent litigation, and therefore favor resolution without hearing. Ultimately, the university will likely consider its own litigation exposure in a manner that could alter its process and decisions of its employees in particular sexual assault cases. Regardless of the specific risk calculation involved, the DCL process will always exist in the shadow of potential future Title IX litigation.

The fear of lawsuit is certainly an issue in any university resolution of a sexual harassment complaint, but the dynamics are different in 
student-to-student sexual assault cases. And when universities have a proven record of intransigence in complying with federal laws related to sexual violence, conflicting motivations might be consistently resolved against victims of sexual assault. Title IX and the DCL framework, to different degrees, still afford universities substantial latitude, which might severely limit their utility at many intransigent schools.

\section{ADVANTAGES TO SAFETY-FOCUSED CODE}

Title IX's role in university sexual assault cases is uncertain and actively evolving. Importantly, it is possible that Title IX need not be applied at all to university sexual assault by and against students. Its role in regards to student-to-student sexual assault cases is a very recent development. ${ }^{46}$ For decades, universities addressed sexual assault accusations and punished those found responsible without any acknowledgement of Title IX. ${ }^{47}$ The long-standing mechanism used to address sexual assault allegations between students has been and remains student codes of conduct. ${ }^{48}$ The use of student codes has left much to be desired and questions remain about their continued utility as well. ${ }^{49}$

Well-designed student safety and conduct codes can address many of the shortcomings of Title IX that are hostile to victims of sexual assault. Adjudication can occur through the same process as other student disciplinary matters. This can lessen common objections to Title IX's application to university sexual assault cases and potentially avoid the growing legitimacy concerns and resultant backlash by using the same rules and procedures as would apply in cases such as theft, assault, or brandishing a firearm.

This is not to say that student safety and conduct codes in their present form are sufficient. Indeed, there is incredible variation among universities in their codes of conduct. Also, the history of student codes in sexual assault cases is poor. ${ }^{50}$ However, legislation, at the state and/or federal level could ameliorate the problems with current student codes. ${ }^{51}$

\footnotetext{
46. Davis v. Monroe Cty. Bd. of Educ., 526 U.S. 629, 647 (1999).

47. See Douglas R. Richmond, Students' Right to Counsel in University Disciplinary Proceedings, 15 J.C. \& U.L. 289, 299 (1989).

48. See Novkov, supra note 37, at 600, 604.

49. See id. at 600-01; see also infra note 50.

50. See, e.g., Doe v. Columbia Univ., 101 F. Supp. 3d 356, 361-76 (S.D.N.Y. 2015); Routh v. Univ. of Rochester, 981 F. Supp. 2d 184, 191-208 (W.D.N.Y. 2013); Vaughan v. Vt. Law Sch., Inc., No. 2:10-CV-276, 2011 WL 3421521, at*1-16 (D. Vt. Aug. 4, 2011), aff'd, 489 F. App'x 505 (2d Cir. 2012); Fellheimer v. Middlebury Coll., 869 F. Supp. 238, 243-47 (D. Vt. 1994).

51. See Katharine Silbaugh, Reactive to Proactive: Title IX's Unrealized Capacity to Prevent
} 
Instead of the various campus safety bills currently being debated, a universal student code would bypass much of the ongoing controversy about campus sexual assault while effectively supplementing the inadequate Title IX regime. The combined effects of Title IX and the new student code legislation would provide a comprehensive policy for campus sexual assault. ${ }^{52}$

\section{A. Fair and Consistent Administration}

One significant advantage to a universal student code is that the procedures used in all disciplinary matters would be the same. If a student is accused of assault, theft, or even homicide, the university administrative apparatus can address each case using the same rules and procedures. Title IX still provides a baseline to ensure that such rules and procedures are constructed and enforced in a non-discriminatory way. However, the need for a specialized sexual assault adjudication process is eliminated.

This universal quality creates several distinct advantages related to case adjudication over a specialized process directed only at sexual assault. At smaller schools, the number of disciplinary hearings in all types of cases is likely few. ${ }^{53}$ Substantial efficiency gains can be achieved by using the same resources and personnel for all cases, or at least all cases related to student safety. ${ }^{54}$

Beyond the resource savings, repetitive use of similar procedures and people can help to ensure consistency. Tribunals are simply more likely to achieve fair application of the relevant law and rules if they are not

Campus Sexual Assault, 95 B.U. L. REV. 1049, 1075 (2015).

52. It is beyond the scope of this Article to outline the entirety of a student conduct code or even all those provisions related to student safety. Nonetheless, a basic substantive code can easily be derived from those already proposed as part of the DCL scheme at the Department of Education. See, e.g., Catherine E. Lhamon \& Jocelyn Samuels, Joint "Dear Colleague" Letter: Nondiscriminatory Administration of School Discipline, OFFICE FOR CIVIL RIGHTS, U.S. DEP'T OF Educ. \& CiviL Rights Div., U.S. DEP’T OF Justice, (Jan. 8, 2014), http://www2.ed.gov/about/offices/list/ocr/letters/colleague-201401-title-vi.html.

53. Smaller schools are likely to have fewer disciplinary hearings per year because the number of disciplinary actions positively correlates with enrollment numbers. See The Campus Safety and Security Data Analysis Cutting Tool, OfFICE OF POSTSECONDARY EduC., U.S. DEP'T OF EdUC., http://ope.ed.gov/Security/ (last visited Mar. 21, 2016).

54. Greater levels of specialization for dealing with particular kinds of disciplinary hearings result in less efficient organizational processes and greater administrative burdens given the procedural similarities and relatively small number of cases. See Michael K. Moch, Structure and Organizational Resource Allocation, 21 ADMIN. SCI. Q. 661, $662-63$ (Dec. 1976) (discussing organizational structures' efficiency generally). 
convened on an irregular, ad hoc basis. ${ }^{55}$ Further, as the present Title IX litigation against universities indicates, a major complaint among plaintiffs from all sides is that the process was not applied in a consistent manner. ${ }^{56}$ By establishing a universal system, courts can evaluate those claims with a real baseline for comparison in place. And from the university perspective, a consistent application of rules can insulate its judgments in safety tribunal proceedings.

The desirability of a fair, consistent, and efficient system of university investigation and adjudication is particularly desirable because of the uncertain legal future of the DCLs. Title IX, in its statutory form, gives no guidance at all to universities regarding sexual assault cases. If a court suddenly invalidated the DCLs, there would be a substantial vacuum in federal regulation. A universal student conduct and safety code would, at a minimum, provide a safety net if such a circumstance arose.

\section{B. Legitimacy and Backlash}

Perhaps the greatest threat to the Title IX and DCL system derives from concerns about its legitimacy and the current backlash against it. After President Barack Obama, in January of 2014, called for greater efforts to address sexual violence at universities, ${ }^{57}$ the response was swift and severe. ${ }^{58}$ Political agendas instantly overrode any pragmatic and thoughtful consideration regarding university student sexual assault. ${ }^{59}$

Emma Sulkowicz, a former student at Columbia University, has become emblematic of the media and social construction of sexual violence at universities. Derisively called "Mattress Girl" by those downplaying concerns about rape, ${ }^{60}$ Sulkowicz attempted to draw

55. See Jay P. Kesan \& Gwendolyn G. Ball, Judicial Experience and the Efficiency and Accuracy of Patent Adjudication: An Empirical Analysis of the Case for a Specialized Patent Trial Court, 24 HARV. J.L. \& TECH. 393, 420-43 (2011) (describing the advantages of having specialized and experienced adjudicators review cases).

56. See supra note 50.

57. See Jennifer Steinhauer, White House to Press Colleges to Do More to Combat Rape, N.Y. Times, Apr. 28, 2014, at A1.

58. See Cathy Young, Guilty Until Proven Innocent: The Skewed White House Crusade on Sexual Assault, Time (May 6, 2014), http://time.com/88407/the-white-houses-report-on-campussexual-assault-relies-on-the-lowest-common-denominator/; Ashe Schow, Backlash: College Men Challenge 'Guilty Until Proven Innocent' Standard for Sex Assault Cases, WASH. EXAM'R (Aug. 11, 2014, 6:00 AM), http://www.washingtonexaminer.com/backlash-college-men-challenge-guilty-untilproven-innocent-standard-for-sex-assault-cases/article/2551863.

59. Id.; see also Ruby Aliment, Comment, Saying "Yes": How California's Affirmative Consent Policy Can Transform Rape Culture, 14 SEATTLE J. FOR Soc. Just. 187, 190-97 (2015).

60. See, e.g., Cathy Young, Did 'Mattress Girl' Tell the Truth? Not Very Likely, Minding THE 
attention to her own experience with campus adjudication in sexual assault cases. ${ }^{61}$ She engaged in a performance art piece, titled "Carry that Weight," wherein she carried the mattress upon which she said she had been raped throughout her remaining time at Columbia. ${ }^{62}$

Response to Sulkowicz was immediate, harsh, and continuous. Googling her name yields a small sampling of the backlash directed at her. ${ }^{63}$ After the Wikipedia entry related to her performance art piece, the next article listed is titled: "Oops, I Guess I Just Raped Emma Sulkowicz." The fourth Google result is: "Did 'Mattress Girl' Tell the Truth? Not Very Likely." 64 The fifth is a New York Times Magazine article covering the story of the man Sulkowicz accused of rape, without any attempt to incorporate Sulkowicz's version of the alleged attack. ${ }^{65}$ A similar story from Newsweek appears in the top results. ${ }^{66}$ The sixth result is an interview with Camille Paglia, a reactionary social commentator, wherein she heavily criticized Sulkowicz's efforts to raise awareness. ${ }^{67}$ Among the first page of Google results, only one linked article, from New York Magazine, includes Sulkowicz's side of the story, but it also discusses criticisms of her choices before and after her alleged attack. ${ }^{68}$

CAMPUS (June 4, 2015), http://www.mindingthecampus.org/2015/06/did-mattress-girl-tell-the-truthnot-very-likely/.

61. Franklin Einspruch, Oops, I Guess I Just Raped Emma Sulkowicz, THE Federalist (June 15, 2015), http://thefederalist.com/2015/06/15/oops-i-guess-i-just-raped-emma-sulkowicz/.

62. $I d$.

63. The Google search was performed on Feb. 6, 2016 and the first page of results contained 12 links described in the main text.

64. Young, supra note 60.

65. Emily Bazelon, Have We Learned Anything From the Columbia Rape Case?, N.Y. Times MAG. (May 29, 2015), http://www.nytimes.com/2015/05/29/magazine/have-we-learned-anythingfrom-the-columbia-rape-case.html?_r=0.

66. Max Kutner, The Other Side of the College Sexual Assault Crisis, NewsweEK (Dec. 10, 2015, 5:33 AM), http://www.newsweek.com/2015/12/18/other-side-sexual-assault-crisis403285.html.

67. Casey Quackenbush, Camille Paglia: Columbia Anti-Rape Mattress Project Is Not Feminism, N.Y. OBSERVER (July 30, 2015, 3:07 PM), http://observer.com/2015/07/camille-pagliacolumbia-anti-rape-mattress-project-is-backwards-feminism/.

68. Vanessa Grigoriadis, Meet the College Women Who Are Starting a Revolution Against Campus Sexual Assault, N.Y. MAG. (Sept. 21, 2014, 9:00 PM), http://nymag.com/thecut/2014/09/emma-sulkowicz-campus-sexual-assault-activism.html. Other links that I have omitted from discussion in the main text are to the hashtags associated with her name at two websites (Jezebel and The Columbia Spectator, Columbia University's student newspaper), two articles related to a video Sulkowicz made enacting a rape that contained many similarities to the accusations she made in her complaint at Columbia, and one article about the reception of Sulkowicz's performance art piece within the larger art community. See Lauren Gambino, Emma Sulkowicz's This Is Not A Rape Site Taken Down by Cyberattack, THE GuARDIAN (June 8, 2015, 8:26 PM), http://www.theguardian.com/us-news/2015/jun/09/emma-sulkowiczs-thisis-not-a-site-taken-down-by-cyberattack; see also Jaleesa Jones, Emma Sulkowicz Uploads Performance Video of Rape, Website Attacked, USA TODAY (June 6, 2015), 
The incredible backlash embodied in the leading news stories linked through a Google search make it hard to believe Professor Glenn Reynold's claim that: "Americans have been living through an enormously sensationalized college rape hoax, but as the evidence accumulates it's becoming clear that the entire thing was just a bunch of media hype and political opportunism." ${ }^{\prime 9}$ Indeed, there are far more prominent and frequent media pieces characterizing sexual assault concerns as a myth or hoax, ${ }^{70}$ than those engaged in serious discussion about the scope of sexual violence on campus.

A universal student safety and conduct code can help lessen substantial portions of the backlash against the Title IX regulatory regime, at least those portions of it that are not wholly ill-intentioned. By treating sexual assault cases in the same manner as other misconduct violations, objections to DCL-mandated procedures lose force. For example, if a university uses a preponderance of the evidence standard of proof for all disciplinary matters - as has long been the case in schools across the country - there should not be any reason to object to its use in sexual assault cases. ${ }^{71}$ If the accused are afforded the same rights regarding counsel in all safety and/or misconduct tribunals, the focus on undoing sexual assault case adjudication should dissipate.

\section{Overrule or Undermine}

Both the doubts about fair administration and substantial hostility can manifest in several ways to undo federal regulation. In its strongest form, backlash could lead to an act by Congress invalidating the DCLs, something that might very well happen if control of the White House shifts in the 2016 election. ${ }^{72}$ However, beyond a complete repeal, subtle

http://college.usatoday.com/2015/06/06/emma-sulkowicz-rape-performance-video/; Roberta Smith, In a Mattress, a Lever for Art and Political Protest, N.Y. TIMES (Sept. 21, 2014), http://www.nytimes.com/2014/09/22/arts/design/in-a-mattress-a-fulcrum-of-art-and-political-

protest.html. The links at Jezebel, a feminist blog affiliated with Gawker Media, are overwhelmingly supportive of Sulkowicz, whereas the links at The Columbia Spectator vary.

69. Reynolds, supra note 3.

70. See, e.g., Naomi Schaefer Riley, The Myth of the College 'Rape Culture', N.Y. Post (Sept. 27, 2015, 6:00 AM), http://nypost.com/2015/09/27/the-myth-of-the-college-rape-culture/.

71. Amy Chmielewski, Note, Defending the Preponderance of the Evidence Standard in College Adjudications of Sexual Assault, 2013 BYU EDUC. \& L.J. 143, 173-74 (2013).

72. Some of the leading 2016 presidential candidates advocated for reducing federal oversight of universities, including eliminating the Department of Education entirely. See Andrew Ujifusa, Envisioning Education Policy Under a President Donald Trump, EdUC. WeEK (Mar. 8, 2016), http://www.edweek.org/ew/articles/2016/03/09/envisioning-education-policy-under-a-presidentdonald.html; Five for Freedom Summary, TED CRUZ 2016, https://www.tedcruz.org/five-forfreedom-summary/ (last visited Mar. 19, 2016). 
efforts to undermine federal regulation can emerge if legitimacy questions persist.

For example, judges might consistently hold that campus tribunals finding misconduct lacked basic procedural protections while also ruling against plaintiffs who contend that universities are failing to adequately protect students from sexual assault. The discretion afforded judges makes reaching both of those results, on a consistent basis, well within their power. Indeed, we might be seeing early signs that judges are acting in exactly that manner.

On February 22, 2016, two federal district courts, in two very different cases, issued opinions regarding motions to dismiss Title IX lawsuits. Samuelson v. Oregon State University was decided by Judge Michael McShane in the U.S. District Court for the District of Oregon. ${ }^{73}$ Judge William E. Smith issued his opinion in Doe v. Brown University in the U.S. District Court for the District of Rhode Island. ${ }^{74}$ In the Oregon case, the plaintiff was a victim of sexual assault suing for failure to properly address her sexual assault complaint. ${ }^{75}$ In the Rhode Island case, a student punished by Brown University filed suit after the university found he committed sexual assault misconduct. ${ }^{76}$ The treatment of the separate Title IX claims raises essential questions.

Judge McShane was very sympathetic to Samuelson's claim and had harsh words for Oregon State University (OSU). This is how the complaint, being reviewed at the motion to dismiss stage, described the essential facts relevant to the Title IX claim:

Plaintiff reported being raped to OSU's sexual assault counselor at OSU's Student Health Services. OSU's sexual assault counselor said to Plaintiff: (a) maybe Plaintiff had said "yes", (b) a rape kit was worse than the assault itself, (c) "these things are hard to prove", (d) it would be blamed on Plaintiff, (e) Plaintiff should not have been drinking, gave her meeting times for Alcoholics Anonymous, and then had no further contact with Plaintiff, and upon information and belief, took no further action. No one else from OSU contacted Plaintiff thereafter about the assault or, upon information and belief, took any other action either. ${ }^{77}$

Judge McShane concluded his harsh assessment of OSU's actions in regard to Samuelson with this stinging rebuke:

73. Samuelson v. Or. State Univ., No. 6:15-cv-01648-MC, 2016 WL 727162, at *1 (D. Or. Feb. 22, 2016).

74. Doe v. Brown Univ., No. 15-144 S, 2016 WL 715794, at *1 (D.R.I. Feb. 22, 2016).

75. Samuelson, $2016 \mathrm{WL} 727162$, at *3.

76. Doe, 2016 WL 715794, at *11.

77. Samuelson, 2016 WL 727162, at *1. 
The university's response to the rapes of Ms. Samuelson and Ms. [Brenda] Tracy was shameful, woefully inadequate, and will remain a dark stain on the history of the institution. Justice and accountability took a back seat to the outdated notion that "boys will be boys" and the truth took a back seat to the desire to attract donors and talented athletes. $^{78}$

Nonetheless, Judge McShane, in dismissing Samuelson's claim with prejudice, took a narrow view of Title IX's jurisdictional limits and found that:

Ms. Samuelson was assaulted not by an OSU student, but by the cousin of an OSU student. Even assuming OSU knew of an "obvious" need for sexual assault training ${ }_{99}$ no one connected to the university sexually assaulted Ms. Samuelson.

In contrast, Judge Smith, in the case against Brown University, allowed a student's suit to advance past a motion to dismiss recognizing that the type of evidence to prove the plaintiff's case would likely only be found through discovery:

One particular challenge in these types of cases is that the best information for discerning whether alleged discrimination was based on the plaintiff's gender as opposed to his status as an accused student is generally in the possession of the defendant: namely, what are the overall outcomes of such cases and, more specifically, how have cases been handled in which the accused student is female and/or the alleged victim is male? ${ }^{80}$

Regarding the Title IX claim, Judge Smith took a far more plaintifffriendly approach in addressing Doe's complaint. Doe certainly alleged sufficient facts that the tribunal reviewing his case might have reached the "wrong" outcome. However, his contention that the outcome was the product of sex discrimination, necessary for an actionable Title IX claim, was based upon limited factual allegations. Nonetheless, Judge Smith concluded these four facts were sufficient to survive Brown University's motion to dismiss:

- Upon information and belief, one former Brown employee stated that Brown treats male students as "guilty, until proven innocent," that Brown has "loaded the dice against the boys"

\footnotetext{
78. Id. at $* 11$.

79. Id. at $* 7$.

80. Doe, 2016 WL 715794 , at *7.
} 
and that the fact-finding process in cases of sexual misconduct at Brown operates under the assumption that it's always the "boy's fault."

- Upon information and belief, one Brown professor stated that "there is gender bias that is overwhelming at Brown" when referencing sexual misconduct cases at Brown.

- Upon information and belief, in December 2014, a Brown professor held a debate to discuss rape issues on campus. During the debate, one female debater remarked that males are "bad" and females are "victims" when it comes to sexual misconduct. The Brown professor stated that these remarks are consonant with the culture of thinking on Brown's campus.

- Upon information and belief, Brown's handing [sic] of John Doe's case fits within a pattern of showing gender bias toward female students in cases of sexual misconduct, including its conduct in: (i) McCormick v. Dresdale... ; (ii) a sexual misconduct case against former Brown student Adam Lack (Class of 1997); and (iii) other instances documented in the Brown Daily Herald (April 29, 2010) and the Brown Spectator (May 26, 2012).

Notably, none of the facts alleged by Doe were directly relevant to his case. They were based upon second-hand information from anonymous sources, media reports of unknown reliability, and general statements made by employees at Brown University who had no known connection to the tribunal where Doe was found responsible.

Both judicial opinions are well within the bounds of judicial discretion. Indeed, in isolation, they both might reflect the perspectives of most judges handling the disputes. The purpose for comparing and contrasting the two opinions is not to indicate that one, both, or neither is wrong.

Rather, the two opinions highlight the reality that Title IX might actually make it easier for those found to have committed a sexual assault to sue universities than victims of sexual assault. In both instances, a plaintiff will need to show, among other things, that the defendant university had actual knowledge of the sex discrimination that was so "severe, pervasive, and objectively offensive" as to be

81. Id. at *8-9 (internal citations omitted). 
actionable. ${ }^{82}$ Those elements are ordinarily met by citing a pattern of sex discrimination similar to that experienced by the plaintiff. ${ }^{83}$

In the case of peer-to-peer sexual assault, proving a pattern and knowledge might be very difficult without discovery. As the Samuelson case illustrates, the university almost never has knowledge of the sexual violence between peers until after it has occurred. As a result, the plaintiff's claim arises from the university's subsequent (mis)handling of the reported sexual assault. Because many sexual assaults occur off campus, university plausible deniability is particularly worrisome. Proving that the university had sufficient knowledge and exhibited a pattern of wrongful behavior can be quite difficult in such cases based solely upon information in the public domain.

In contrast, when a student is punished after being found responsible for sexual misconduct during a campus tribunal, the key elements of a Title IX claim are often easier to establish. The university clearly has knowledge of the alleged discriminatory event, which was the finding of a campus tribunal. And information about prior adjudications, while not completely transparent, is often easily available through, as in Doe's case, local media reports and limited public documents. As a result, the structure of a Title IX cause of action, at least at the early stages of litigation, might be more favorable to the person found to have sexually assaulted another student than to the victim of sexual violence.

A student safety and conduct code does not suffer from the same inherent bias. By using the lens of student safety to determine wrongdoing, the university and courts reviewing the university's findings are free to address the basic question of whether the procedures were fair and the outcome just (with or without a standard of deference applied). Title IX, as a means of holding universities accountable for their failure to properly address sexual assault, is still largely untested in federal courts. It would be a horrible twist if the courts primarily used Title IX as a sword against, and not a shield protecting, university victims of sexual violence.

\section{CONCLUSION}

It is still too early to judge whether Title IX's central role in regards to university student sexual violence will be a net positive. Most Title IX

82. Id. at*14-15; Samuelson, 2016 WL 727162, at*5.

83. Jenni E. Spies, Comment, Winning at All Costs: An Analysis of a University's Potential Liability for Sexual Assaults Committed by Its Student Athletes, 16 MARQ. SPORTS L. REV. 429, 44950 (2006). 
investigations of schools are unresolved. ${ }^{84}$ Even among those universities for which the Department of Education has completed its investigations, there is little information or data available to assess whether the regulatory scrutiny will have long-term effects. Litigation of Title IX complaints is even further behind with few cases having advanced beyond initial motions. At this time, then, it is simply impossible to give confident conclusions about Title IX's significance concerning university sexual violence. There also remain questions unresolved by prior Title IX litigation such as whether incidents that do not fit the heterosexual formulation will be considered as "sex discrimination" as required by the statute. ${ }^{85}$

As a result, this Article's contentions and conclusions should be read not as condemnations of the Title IX framework. Rather, the arguments herein represent possible concerns that should be addressed either within Title IX's regulatory scheme, court doctrine, or through supplementary legislation such as a universal student safety and conduct code proposed in this Article. Even if all of the fears articulated in this Article are validated, Title IX still has a very important role to play. It can continue to serve as an important safety net in enabling a cause of action when universities exhibit patterns of sex discrimination. It also ensures that the essential civil rights component of sexual violence is addressed.

This Article offers an approach that is not exclusive of, but rather complementary toward Title IX. Just as we must not overlook how sexual violence, and handling of incidents of such violence, implicates civil rights based upon sex, we should not ignore the connections between sexual violence and other actions that threaten student safety. Campus rape should not just be viewed through the lens of sexual harassment law. It is essential that rules governing adjudication and punishment for rape are connected and similar to rules in instances where a student commits murder, assault, battery, or any number of violent acts. By uniting and harmonizing university sexual assault policies with those for other threats to student safety, much of the backlash against such rules might be defused. Further, by focusing on how sexual violence by and against students is not just about a statute that places universities squarely in the role of a defendant in potential future litigation, revived

\footnotetext{
84. Tyler Kingkade, 124 Colleges, 40 School Districts Under Investigation for Handling of Sexual Assault, HufFington Post (July 24, 2015, 2:06 PM), http://www.huffingtonpost.com/entry/schools-investigation-sexualassault_us_55b19b43e4b0074ba5a40b77.

85. See Amanda Bryk, Title IX Giveth and the Religious Exemption Taketh Away: How the Religious Exemption Eviscerates the Protection Afforded Transgender Students Under Title IX, 37 CARDOZO L. REV. 751, 764 (2015).
} 
and improved student safety and conduct codes can lessen perceived and real conflicts of interest that emerge among university officials. And given some genuine questions about how courts will rule in regards to the legal status and legal relevance of the DCLs, legislation for a universal student safety and conduct code would ensure legal stability and certainty so that students and university officials can effectively comply with the law.

In the end, in what is surely an unusual desire for an author, I hope I am entirely wrong about what I have argued here. Ideally, Title IX can fulfill its promise in helping to protect students from victimization while providing adequate protections to the accused. And the warts of the current regulatory regime are corrected or overcome. When it comes to sexual violence, though, it is probably best to hope for the best, but plan for the worst. A universal campus safety and conduct code can provide important insurance that a fair and effective legal regime can help protect students at universities throughout the United States. 